\title{
Population response of Helicoverpa armigera on sunflower treated with botanical synthetic insecticides
}

Muhammad Ibrahim Mengal ${ }^{1 *}$, Shabeer Ahmed ${ }^{1}$, Manzoor Ahmed ${ }^{2}$, Abdul Nabi ${ }^{1}$, Muhammad Aamir Tariq ${ }^{1}$, Fazal Muhammad Bangulzai ${ }^{1}$, Abdul Rauf Zehri ${ }^{1}$, Shah Alam ${ }^{1}$, Abdul Ghaffar ${ }^{1}$, Syed Shah ${ }^{1}$, Naseer Ahmed Shahwani ${ }^{1}$, Muhammad Akbar Badini ${ }^{1}$ and Mitha Khan ${ }^{1}$

1. Agriculture Research Institute (A.R.I) Sariab Quetta, Balochistan, Pakistan

2. Balochistan Agriculture College Quetta, Pakistan

*Corresponding author's email: shabeerahmed6464@gmail.com

\section{Citation}

Muhammad Ibrahim Mengal, Shabeer Ahmed, Manzoor Ahmed, Abdul Nabi, Muhammad Aamir Tariq, Abdul Rauf Zehri, Shah Alam, Abdul Ghaffar, Syed Shah, Naseer Ahmed Shahwani, Fazal Muhammad, Muhammad Akbar Badini and Mitha Khan. Population response of Helicoverpa armigera on sunflower treated with botanical synthetic insecticides. Pure and Applied Biology. Vol. 10, Issue 4, pp1477-1483.

http://dx.doi.org/10.19045/bspab.2021.100153

\begin{tabular}{|c|c|}
\hline & $4 / 2022$ \\
\hline
\end{tabular}

\section{Abstract}

To study to the population response of Helicoverpa armigera on sunflower treated with botanical and synthetic insecticides. Four treatments with $\mathrm{T}_{1}=\mathrm{Neem}$ kernel powder, $\mathrm{T}_{2}=$ Garlic solution, $\mathrm{T}_{3}=$ Steward and control (untreated). $\mathrm{T}_{3}$ showed highest reduction percentage $(53.25 \%)$ and $(47.64 \%)$ after three and five days spray, followed by $\mathrm{T}_{1}$ the plots treated with neem seed kernel extracts $(49.39 \%)$ and $(41.13 \%), \mathrm{T}_{2}(32.60 \%)$ and $(28.44 \%)$. The minimum reduction percentage was recorded in untreated plot (13.47\%) and (15.33\%) three and five days after spray, respectively. In the second spray $\mathrm{T}_{3}$ also showed highest reduction percentage $(64.39 \%)$ and $(58.99 \%)$ after three and five days spay followed by $\mathrm{T}_{1},(61.46 \%)$ and $(54.23 \%), \mathrm{T}_{2}$ Garlic solution (47.42\%) and $(42.39 \%)$. The minimum reduction percentage was recorded in the control plot $(14.11 \%)$ and $(11.43 \%)$ respectively. However, in $3^{\text {rd }}$ spray the highest reduction percentage was recorded in $\mathrm{T}_{3}$ $(54.11 \%)$ and $(48.67 \%)$ after three and seven days followed by $\mathrm{T}_{1}(50.15 \%)$ and $(47.81 \%), \mathrm{T}_{2}$ $(38.61 \%)$ and $(35.16 \%)$ The minimum reduction percentage was recorded in the untreated plot $(13.60 \%)$ and $(12.51 \%)$ after three and seven respectively. While, in fourth spray, the heighest reduction percentage was recorded in $\mathrm{T}_{3}(70.62 \%)$ and $(39.40 \%)$ after three and five days followed by $\mathrm{T}_{1}(39.37 \%)$ and $(24.44 \%), \mathrm{T}_{2}(22.37 \%)$ and $(7.53 \%)$. The minimum reduction percentage was recorded in untreated plot $(14.28 \%)$ and $(13.35 \%)$ after three and five days respectively. The overall results showed that the bio pesticides reduced Helicoverpa armigera population progressively, as compare to control.

Keywords: Helicoverpa armigera; Spray; Sunflower; Organic Pesticide

Introduction

Sunflower, Helianthus annuus (L.) belongs to the family Compositeae, locally it is known as Surajmukhi [1, 2]. The oil is 
palatable, contains soluble vitamins $\mathrm{A}, \mathrm{D}, \mathrm{E}$ and $\mathrm{K}$ seed meal of sunflower is rich source of food for fattening animals and poultry birds. There is a need of the day that its area, production and protection should be enhanced [3]. Among these sucking pests the leafhopper, Amrasca biguttula biguttula, Ishida (Hemiptera: Cicadellidae) is economically important Pest [4]. Amrasca biguttula biguttula is polyphagous pest of many agricultural and nonagricultural plants. It sucks the cell sap from leaves, flowers, fruits and tender stems and affects the growth of crop plants adversely. It also creates sooty mould on crop leaves which affect photosynthesis, growth and yield of the crops [5].

Helicoverpa armigera (Hub.) is a major pest of important crops and vegetables in Pakistan It has been recorded to damage more than 100 plants species including cultivated and non cultivated plants of 39 families across the world [6]. Host species for $H$. armigera come from a broad spectrum of families and include important agricultural. It invades and voraciously feeds on cash crops such as cotton, maize, chickpea, pigeonpea, sorghum, sunflower, soyabean and groundnuts around the world [7].

The indiscrimination use of chemical poisons has disturbed the natural ecosystem and the natural balance ratio of pests and its natural enemies. The pesticides do not kill the pests alone but also destroy the predator; parasites, animals, birds, and some time human being get seriously affected while using the spray material. The pesticides are the only readily available source for destroying pest population in many developing countries [8]. In the present study, neem seed kernel and garlic solution will be tested against Helicoverpa armigera on sunflower which will not destroy natural enemies and is safe to environment. The products will be compared with control plot where Steward pesticide will be applied for comparison. The proposed IPM strategy will be useful information for the management of Helicoverpa armigera on sunflower crop. Bio-pesticides natural substance occurring compounds non-toxic which are used for control of insect pests. Synthetic pesticides (conventional) has been also known for killing / inactivation of insect pests. On the other hand biochemical pesticides which consists of plant growth regulators for control of growth or mating as well as repel or in attract pests such as pheromones [9].

In view of the environmental and health issues the bio-pesticides are holding attention by scientists and researchers as they are safe and environment friendly [10]. Although numerous methods are employed to combat insect pests, but controlling these insect pests through pesticidal application is yet more efficacious compared to rest of the methods. However, pesticide application is only recommended when insect buildup crosses ETL [11] because synthetic insecticides has contributed to the environmental pollution through air or as residues in food [12]. Hence, inclusion of environmental friendly biopesticides in the spray program, such as plant extracts could be best option to minimize reliance on synthetic pesticides for insect pest management in okra. The diverse biological activities of plant extracts include feeding and oviposition deterrence, repellency, growth disruption, reduced fitness, and sterility [13]. The rapid increase in pesticide use on field crops is alarming and emphasizes farmers ${ }^{\text {ee }}$ concern with insect pests. The trends also highlight the need for safe and effective management strategies. The difficulty in managing insecticide resistant populations of Helicoverpa armigera has given impetus to the development and use of alternative, and has less negative impact on beneficial organisms than conventional insecticides.

\section{Materials and Methods}

An experiment was carried out to assess the 
population response of Helicoverpa armigera on sunflower treated with botanical and synthetic insecticides at experimental area of Pussia Goth near Tandojam, during 2016. Four treatments such as $\mathrm{T} 1=$ Neem kernel powder, T2= Garlic solution, T3= Steward 150 SC (Indoxacarb) and T4= control (Untreated) was evoluted against the $H$. arimgera on sunflower crop. Variety HO1 was sown on $1^{\text {st }}$ March 2016 for this purpose. The experiment was laid out in a Randomized Complete Block Design with four treatments and three replications, in a field measuring about plot size was $1245 \mathrm{~m}^{2}$ (12 ghuna) and sub plot size was $207 \mathrm{~m}^{2}$ (2 ghunta). Eight $\mathrm{kgs}$ of neem kernel was grounded through grinder and soaked for 24 hours, 15 liters of 5\% EC suspension was obtained. As such, 20 gm grinded garlic bulbs with 10 gm detergent were put separately in muslin cloth and added to one liter of water and kept for 24 hours which gave us 5\% solution were sprayed against $H$. armigera as compare with untreated control. The synthetic pesticide "Steward " was obtained from the market. The Steward applied with the dose of $175 \mathrm{ml}$ per acre. Four sprays were done during the morning hours, the $1^{\text {st }}$ spray was done on 15-04-2016, while second, third and fourth sprays was applied after 15 days intervals respectively. For this purpose, a hand operated knapsack sprayer was used. For recording observation on population of Helicoverpa armigera twenty-five plants were selected randomly from each sub plot and tagged were examined carefully and their average was workout. Three observations were taken for each application i.e. one day before spray (Pre-treatment observation) and two observations after sprays (Post treatment) at the intervals of three and five days. The effect of pesticides reduction percentage was calculated as per the standard formula of [14].

Percent mortality $=\frac{1-\mathrm{Ta} \times \mathrm{Ca} \times 100}{\mathrm{~Tb} \mathrm{Cb}}$
Where

$\mathrm{Tb}=$ Number of pest in treated plots before treatment.

$\mathrm{Ta}=$ Number of pest in treated plots after treatment.

$\mathrm{Cb}=$ Pest population in the control plots before treatment.

$\mathrm{Ca}=$ Pest population in the control plots after treatment.

The data thus collected were subjected to analysis of various to test superiority of treatment mean LSD test was applied as per the method outline by [15]. For this purpose, a Microsoft computer package "MSTATC" was used.

\section{Results}

In order to evaluate the efficacy of different pesticides against Helicoverpa armigera on sunflower crop was carried out during the year 2016, at the experimental area of Pussia goth near Tandojam. The biopesticides and synthetic pesticide included $\mathrm{T} 1=$ Neem kernel powder, $\mathrm{T} 2=$ Garlic solution, $\mathrm{T} 3=$ Steward $150 \mathrm{SC}$ (Indoxacarb) and $\mathrm{T}=4$ Control (Untreated). Sprays was done when Helicoverpa armigera were appeared on sunflower crop, sprays were carried out in the months of mid-April to mid-June, respectively. The results of present studies are given below.

Reduction \%age of different pesticides against $\boldsymbol{H}$. armigera on sunflower crop was recorded before and after different time intervals of $1^{\text {s }}$ spray

The result on reduction \%age of Helicoverpa armigera recorded after three and five days after $1^{\text {st }}$ spray of different treatments are shown in the (Table 1). It may be seen from the results that the biopesticides reduce Helicoverpa armigera population progressively, as compared to control. The neem seed kernel extracts showed maximum reduction \%age after three and five days of $1^{\text {st }}$ sprays as compared garlic solution. The maximum reduction percentage was recorded 
in the plots treated with Steward (53.25\%) and $(47.64 \%)$ after three and five days spray, followed by the plots treated with Neem seed kernel extracts $(49.39 \%)$ and $(41.13 \%)$, Garlic solution $(32.60 \%)$ and $(28.44 \%)$ and the minimum reduction percentage was recorded in the control (untreated) plots $(13.47 \%)$ and $(15.33 \%)$ three and five days after spray, respectively.

Reduction \%age of different pesticides against Helicoverpa armigera on sunflower crop was recorded before and after different time intervals of $2^{\text {nd }}$ spray.

The result on reduction \%age of Helicoverpa armigera was recorded after the different time intervals of 2nd spray of different treatments was shown in the (Table 2). It could be seen from the results of $2^{\text {nd }}$ spray; in the same way of the $1^{\text {st }}$ spray. The neem seed kernel extracts showed maximum reduction percentage after three and five days after $2^{\text {nd }}$ spray as compare to garlic and control plots. The maximum reduction percentage was recorded in the plots treated with Steward (64.39\%) and (58.99\%) after three and five days after $2^{\text {nd }}$ spray, followed by the plots treated with neem seed kernel extracts $(61.46 \%)$ and $(54.23 \%)$, garlic solution $(47.42 \%)$ and $(42.39 \%)$ and the minimum reduction percentage was recorded in the control plot (14.11\%) and (11.43\%) after three and five days after 2nd spray, respectively.

Reduction \%age of different pesticides against Helicoverpa armigera on sunflower crop before and after different time intervals of $3^{\text {rd }}$ spray.

After $3^{\text {rd }}$ spray the results showed that the reduction \%age of Helicoverpa armigera was recorded after the different time intervals of 3rd spray of different treatments was shown in the (Table 3 ). After the $3^{\text {rd }}$ spray neem seed kernel extracts showed maximum reduction \%age after three and seven days after spray as compare to garlic and control plots. The maximum reduction percentage was recorded in the plots treated with Steward $(54.11 \%)$ and $(48.67 \%)$ after three and seven days after $3^{\text {rd }}$ spray, followed by the plots treated with neem seed kernel extracts $(50.15 \%)$ and $(47.81 \%)$, garlic solution $(38.61 \%)$ and $(35.16 \%)$ and the minimum reduction percentage was recorded in the untreated plot (13.60\%) and (12.51\%) after three and seven days after 3rd spray, respectively.

Reduction \%age of different pesticides against Helicoverpa armigera on sunflower crop before and after different time intervals of $4^{\text {th }}$ spray

After $4^{\text {th }}$ spray the results showed that the reduction \%age of Helicoverpa armigera was recorded after the different time intervals of $4^{\text {th }}$ spray of different treatments was shown in the (Table 4). After the 4th spray the maximum reduction percentage was recorded in the plots treated with Steward (70.62\%) and $(39.40 \%)$ after three and five days after $4^{\text {th }}$ spray, followed by the plots treated with Neem seed kernel extracts $(39.37 \%)$ and $(24.44 \%)$, Garlic solution $(22.37 \%)$ and $(7.53 \%)$ and the minimum reduction percentage was recorded in the control plots $(14.28 \%)$ and $(13.35 \%)$ after three and five days after 4th spray, respectively.

\section{Yield per plot/acre ${ }^{-1}$}

Yield per plot/acre ${ }^{-1}$ was higher (23.20 per plot and $464 \mathrm{~kg} \mathrm{acre}^{-1}$ ) in plot sprayed with Steward and the lowest yield of $7.10 \mathrm{kgs}$ per plot and $142 \mathrm{kgs}$ acre $^{-1}$ was recorded in control, while among treated plots the lowest sunflower yield of $19.58 \mathrm{Kgs}$ per plot and $391.60 \mathrm{kgs} \mathrm{acre}^{-1}$ was recorded in plots sprayed with garlic solution (Table 5). 
Table 1. Mean and reduction \%age of different pesticides against $\boldsymbol{H}$. armigera on sunflower crop was recorded before and after different time intervals of $1^{\mathrm{s}}$ spray

\begin{tabular}{|c|c|c|c|}
\hline Treatments & Pretreatment Observation & 3 Day After Spray & 5 Day After Spray \\
\hline Steward & $2.63 \mathrm{c}$ & $53.25 \mathrm{a}$ & $47.64 \mathrm{a}$ \\
\hline Neem seed kernel & $2.53 \mathrm{~d}$ & $49.39 \mathrm{~b}$ & $41.13 \mathrm{~b}$ \\
\hline Garlic solution & $2.83 \mathrm{~b}$ & $32.60 \mathrm{c}$ & $28.44 \mathrm{c}$ \\
\hline Control & $3.23 \mathrm{a}$ & $13.47 \mathrm{~d}$ & $15.33 \mathrm{~d}$ \\
\hline SE \pm & 0.4142 & & \\
\hline LSD 0.05 & 3.6846 & & \\
\hline
\end{tabular}

Table 2. Mean and reduction $\%$ age of different pesticides against $\boldsymbol{H}$. armigera on sunflower crop was recorded before and after different time intervals of $2^{\text {nd }}$ spray

\begin{tabular}{|c|c|c|c|}
\hline Treatments & Pre-treatment Observation & 3 Day After Spray & 5 Day After Spray \\
\hline Steward & $2.13 \mathrm{~d}$ & $64.39 \mathrm{a}$ & $58.99 \mathrm{a}$ \\
\hline Neem seed kernel & $2.26 \mathrm{c}$ & $61.46 \mathrm{~b}$ & $54.23 \mathrm{~b}$ \\
\hline Garlic solution & $2.36 \mathrm{~b}$ & $47.42 \mathrm{c}$ & $42.39 \mathrm{c}$ \\
\hline Control & $2.68 \mathrm{a}$ & $14.11 \mathrm{~d}$ & $11.43 \mathrm{~d}$ \\
\hline SE \pm & 0.3245 & & \\
\hline LSD 0.05 & 3.2451 & & \\
\hline
\end{tabular}

Table 3. Mean and reduction \%age of different pesticides against $\boldsymbol{H}$. armigera on sunflower crop before and after different time intervals of $3^{\text {rd }}$ spray

\begin{tabular}{|c|c|c|c|}
\hline Treatments & Pre-treatment observation & 3 Day After Spray & 5 Day After Spray \\
\hline Steward & $1.57 \mathrm{a}$ & $54.11 \mathrm{a}$ & $48.67 \mathrm{a}$ \\
\hline Neem seed kernel & $2.13 \mathrm{~b}$ & $50.15 \mathrm{~b}$ & $47.81 \mathrm{~b}$ \\
\hline Garlic solution & $1.57 \mathrm{c}$ & $38.61 \mathrm{c}$ & $35.16 \mathrm{c}$ \\
\hline Control & $2.54 \mathrm{a}$ & $13.60 \mathrm{~d}$ & $12.51 \mathrm{~d}$ \\
\hline SE \pm & 0.3621 & & \\
\hline LSD 0.05 & 3.4712 & & \\
\hline
\end{tabular}

Table 4. Mean and reduction \%age of different pesticides against $\boldsymbol{H}$. armigera on sunflower crop before and after different time intervals of $4^{\text {th }}$ spray

\begin{tabular}{|c|c|c|c|}
\hline Treatments & Pre-treatment Observation & 3 Day After Spray & 5 Day After Spray \\
\hline Steward & $0.99 \mathrm{~d}$ & $70.62 \mathrm{a}$ & $39.40 \mathrm{a}$ \\
\hline Neem seed kernel & $1.03 \mathrm{c}$ & $39.37 \mathrm{~b}$ & $24.44 \mathrm{~b}$ \\
\hline Garlic solution & $1.40 \mathrm{~b}$ & $22.37 \mathrm{c}$ & $7.53 \mathrm{c}$ \\
\hline Control & $2.29 \mathrm{a}$ & $14.28 \mathrm{~d}$ & $13.35 \mathrm{~d}$ \\
\hline SE \pm & 0.3416 & & \\
\hline LSD 0.05 & 2.4160 & & \\
\hline
\end{tabular}


Table 5. Yield per plot/acre ${ }^{-1}$ sprayed with various pesticides

\begin{tabular}{|c|c|c|c|c|c|}
\hline Treatments & RI & RII & RIII & $\begin{array}{c}\text { Average yield per plot } \\
(\mathbf{k g})\end{array}$ & $\begin{array}{c}\text { Average yield acre }^{-1} \\
(\mathbf{k g})\end{array}$ \\
\hline Steward & 24 & 22.60 & 23 & $23.20 \mathrm{a}$ & $464.00 \mathrm{a}$ \\
\hline $\begin{array}{c}\text { Neem seed } \\
\text { kernel }\end{array}$ & 22.50 & 23 & 21.50 & $22.33 \mathrm{a}$ & $446.60 \mathrm{a}$ \\
\hline Garlic solution & 20.50 & 19.75 & 18.50 & $19.58 \mathrm{~b}$ & $391.60 \mathrm{~b}$ \\
\hline Control & 7.5 & 8.00 & 6.00 & $7.10 \mathrm{c}$ & $142.00 \mathrm{c}$ \\
\hline S.E \pm & 25.759 & & & & \\
\hline LSD 0.05 & 57.394 & & & & \\
\hline LSD 0.01 & 81.636 & & & & \\
\hline
\end{tabular}

\section{Discussion}

The indiscrimination use of chemical poisons has disturbed the natural ecosystem and the natural balance ratio of pests and its natural enemies. The pesticides do not kill the pests alone but also destroy the predator; parasites, animals, birds, and some time human being get seriously affected while using the spray material. The pesticides are the only readily available source for destroying pest population in many developing countries [8]. In the present study, neem seed kernel and garlic solution will be tested against Helicoverpa armigera on sunflower which will not destroy natural enemies and is safe to environment. The products will be compared with control plot where Steward pesticide will be applied for comparison. The proposed IPM strategy will be useful information for the management of Helicoverpa armigera on sunflower crop. The present results showed that Neem Seed Kernal Extracts reduce the maximum reduction percentage of $H$. armigera on sunflower followed by Garlic solution and control but their effect was nonsignificant with control. The results are partially in agreement with those of [16] also stated that the neem seed kernel extract can be used against $H$. armigera instead of highly toxic synthetic insecticides. [17] proved that the neem seed kernel extract in chloroform: methanol (9:1) was the most promising in causing adverse effects on Helicoverpa armigera.
There are reports where neem seed kernel extract and pure compounds obtained from neem seed kernel extract had been found to produce diverse biological effects on insects: antifeedant oviposition deterrent etc. Of these antifeedant activity of neem was considered very important. [18] found Bollcure fraction $(0.15 \%)$, Bollcure fraction $(0.25 \%)$ and neem seed kernel extract (az 1500 ppm) are relevant as most effective and economical treatments in reducing the larval population of Helicoverpa armigera in chickpea. Our findings are agreed with the findings of [19] they reported that effect of bio-pesticides at 10 days' intervals and recorded the heighest yield.

\section{Conclusion and Recommendations}

On the basis of results obtained from field trials among the pesticide/biopesticides applied, Neem Seed Kernal extracts and Garlic solution significantly reduced the Helicoverpa armigera population on sunflower field. Neem Seed Kernal Extracts proved to be most effective bio-pesticide against Helicoverpa armigera to suppress the population as compared to Garlic solution and control, after $1^{\text {st }}, 2^{\text {nd }} 3^{\text {rd }}$ and $4^{\text {th }}$ spray. Garlic solution was also found the most effective to suppress the population of Helicoverpa armigera as compare to control on sun flower. On the basis of findings of the present research it is suggested that Neem Seed Kernal extracts may be applied more preferable against Helicoverpa armigera on 
sunflower field, followed by Garlic solution and synthetic pesticides.

\section{Authors' contributions}

Conceived and designed the experiments: $\mathrm{M}$ Ibrahim \& $S$ Ahmed, Performed the experiments: $\mathrm{M}$ Ibrahim \& $\mathrm{S}$ Ahmed, Analyzed the data: F Muhammad, Contributed reagents/ materials/ analysis tools: N Alizai, M Ahmed \& A Nabi, Wrote the paper: M Ibrahim \& S Ahmed.

\section{References}

1. Shirshikar SP (2005). Mildew disease in India. Helia. 28: 153-158.

2. Skoric DS, Jocic N, Lecic \& Sakac Z (2007). Development of sunflower hybrids with different oil quality. Helia 30: 205-212.

3. Singh KK, Mridula D, Rehal J \& Barnwal P (2011). Flaxseed: a potential source of food, feed and fiber. Crit Rev in Food Sci and Nutr 51(3): 210-222.

4. Singh, Satnam, et al. (2018)"Selection of housekeeping genes and demonstration of RNAi in cotton leafhopper, Amrasca biguttula biguttula (Ishida). PLoS One 13.1: e0191116.

5. Kamble CS \& Sathe TV (2015). Incidence and host plants for Amrasca biguttula (Ishida) from Kolhapur region, India. Inters J Dev Res 5(3): 3658-3661.

6. Rai AB, Halder J \& Kodandaram, M H (2014). Emerging insect pest problems in vegetable crops and their management in India: An appraisal. Pest Manag in Hortic Ecosys 20(2): 113-122.

7. Khuhro, Ali S, Lanjar AG \& Solangi AW (2014). Efficacy of Neem Kernal Powder and Neem Oil against Helicoverpa armigera on Sunflower Crop. J Nat Sci Res 4(7): 45-49.

8. Lohar MK (2001). General Entomology (Ist Edition). Department Entomology Sindh Agriculture Universities Tando Jam.

9. Thakore Y (2006). The biopesticide market for global agriculture use. Indus Biotechnol Fall 194-208.

10. Srinivasan G \& Babu PCS (2001). Field evaluation of neem products against whitefly, fruit borer Bemisia tabaci Gennadius on brinjal. Ann Plant Prot Sci 9(1): 19-21.

11. Matthews, Graham. Pesticide application methods. John Wiley \& Sons, 2008.

12. Edwards, CA ed (2013). Environmental pollution by pesticides (Vol 3). Springer Sci \& Business Media.

13. Ghosh, GK 2000. Biopesticide \& integrated pest management. APH Pub.

14. Esu E, Lenhart A, Smith L \& Horstick O (2010). Effectiveness of peridomestic space spraying with insecticide on dengue transmission; systematic review. Trop Med \& Inter Heal 15(5): 619-631.

15. Gomez KA \& Gomez AA (1984). Statistical procedures for agricultural research (2 ed.). John Wiley and Sons, NewYork, pp. 680.

16. Thakur RC, Nema KK \& Kango KN (1988). Comparative efficacy of neem seed kernel and some insecticidal formulations against the grain pod borer, Heliothis armigera (Hübner). Legume Res 11: 114-116.

17. Jaglan MS, Khokhar KS, Malik MS \& Singh R (1997). Evaluation of neem (Azadirachta indica A. Juss) extracts against American bollworm, Helicoverpa armigera (Hubner). J Agric Food Chem 45(8): 3262-3268.

18. Reghuraman M, Ajanta B \& Gupta GP (2008). Management of Helicoverpa armigera in chickpea with botanical formulations. Indi J of Entol 70(2): 118 122.

19. Bhushan S, Singh RP \& Shanker R (2011). Bioefficacy of neem and Bt against pod borer, Helicoverpa armigera in chickpea. $J$ of Biopesticides 4(1): 87. 